\title{
Streptosporangium fragile sp. nov.
}

\author{
MARCIA C. SHEARER, ${ }^{1 *}$ PAULA M. COLMAN,${ }^{1}$ AND CLAUDE H. NASH III ${ }^{2}$ \\ Department of Natural Products Pharmacology, Smith Kline \& French Laboratories, Philadelphia, \\ Pennsylvania 19101, ${ }^{1}$ and Sterling-Winthrop Research Institute, Rensselaer, New York $12144^{2}$
}

A new species of Streptosporangium is described, for which we propose the name Streptosporangium fragile. This organism produces a new anthracycline antibiotic and is characterized by dark brown to black vegetative mycelium, pink aerial mycelium, brown soluble pigment, and fragile sporangial membrane. In older cultures the fragility of the sporangial membrane results in the coalescence of the sporangiospores into large irregular masses. The type strain of $S$. fragile is SK\&F-BC2496 (= ATCC 31519).

The genus Streptosporangium was originally described by Couch (4) to include actinomycetes that are characterized by the formation of nonmotile sporangiospores which are arranged in a coil within a sporangium. During the course of screening for new antibiotics, we isolated a morphologically and physiologically distinct strain of Streptosporangium, strain SK\&FBC2496 ${ }^{\mathrm{T}}$ (type strain), which produces a novel anthracycline antibiotic. In this report we provide data to support the recognition of a new species, for which we propose the name Streptosporangium fragile. The isolation and characterization of the anthracycline antibiotic have been described (C. H. Nash III, M. C. Shearer, K. M. Snader, J. R. Valenta, and D. Cooper, U.S. patent 4,293,546, October 1981).

\section{MATERIALS AND METHODS}

Bacterial strain and culture conditions. Strain SK\&F-BC2496 ${ }^{\mathrm{T}}$ was isolated by standard soil dilution and plating techniques from a soil sample collected in the Northern Province of Sri Lanka. The soil sample was taken from a cultivated field that was lying fallow after a paddy crop.

Stock cultures were grown on medium 172 (1); temperature relationships were also determined on slants of this medium. The medium used for morphological observations was oatmeal agar (25). Additional media used to characterize strain SK\&F-BC2496 ${ }^{\mathrm{T}}$ were yeast extract-malt extract agar (25), inorganic salts-starch agar (25), glycerol-asparagine agar (25), peptone-yeast extract-iron agar (25), tyrosine agar (25), potato dextrose agar (Difco Laboratories) with the $\mathrm{pH}$ adjusted to 7.0 to 7.2, Czapek-Dox broth (Difco) solidified with agar, Bennett agar (13), Czapekpeptone agar (5), Emerson YpSs agar (7), thin potatocarrot agar (11), defined agar (16), nutrient gelatin (Difco), and litmus milk medium (Difco).

All tests were performed at $28^{\circ} \mathrm{C}$. For growth tests under anaerobic conditions, the GasPak system (BBL Microbiology Systems) was used.
Microscopy. For scanning electron microscopy, 14day-old plate cultures of strain SK\&F-BC2496 ${ }^{\mathrm{T}}$ on Jensen agar (12) were fixed with osmium tetroxide in situ and gold-shadowed by conventional techniques. The shadowed specimens were viewed with a Jeol 100CX ASID-4D scanning electron microscope.

Physiological tests. The physiological tests used to characterize strain SK\&F-BC2496 ${ }^{T}$ were those of Gordon $(8,9)$ and Gordon and Mihm (10). In the tests for acid production from carbohydrates and utilization of organic acids, all results were confirmed by subculturing onto fresh medium.

Organic growth factor requirements were investigated with a synthetic medium containing the following: dextrose, $15 \mathrm{~g} ; \mathrm{K}_{2} \mathrm{HPO}_{4}, 3 \mathrm{~g} ; \mathrm{KH}_{2} \mathrm{PO}_{4}, 0.5 \mathrm{~g}$; $\mathrm{MgCl}_{2} \cdot 6 \mathrm{H}_{2} \mathrm{O}, 0.53 \mathrm{~g} ; \mathrm{CaCl}_{2}, 0.01 \mathrm{~g} ; \mathrm{NaCl}, 1.0 \mathrm{~g}$; $\mathrm{FeCl}_{3} \cdot 6 \mathrm{H}_{2} \mathrm{O}, 0.001 \mathrm{~g}$; mineral solution, $10 \mathrm{ml}$; and distilled water, $1,000 \mathrm{ml}$. The $\mathrm{pH}$ of this medium was 7.1. The mineral solution contained the following: $\mathrm{ZnSO}_{4} \cdot 7 \mathrm{H}_{2} \mathrm{O}, 2.8 \mathrm{~g}$; $\mathrm{CuSO}_{4} \cdot 5 \mathrm{H}_{2} \mathrm{O}, 0.125 \mathrm{~g}$; $\mathrm{MnSO}_{4} \cdot \mathrm{H}_{2} \mathrm{O}, 1.0 \mathrm{~g} ; \mathrm{CoCl}_{2} \cdot 6 \mathrm{H}_{2} \mathrm{O}, 0.1 \mathrm{~g}$; $\mathrm{Na}_{2} \mathrm{~B}_{4} \mathrm{O}_{7} \cdot 10 \mathrm{H}_{2} \mathrm{O}, 0.09 \mathrm{~g} ; \mathrm{Na}_{2} \mathrm{MoO}_{4} \cdot 2 \mathrm{H}_{2} \mathrm{O}, 0.05 \mathrm{~g}$; and distilled water, $1,000 \mathrm{ml}$. The following nitrogen sources were tested: $\mathrm{NaNO}_{3}(3 \mathrm{~g} /$ liter $),\left(\mathrm{NH}_{4}\right)_{2} \mathrm{SO}_{4}(3$ g/liter), L-asparagine ( $3 \mathrm{~g} /$ liter), and $\left(\mathrm{NH}_{4}\right)_{2} \mathrm{SO}_{4}$ plus Lasparagine (each $1.5 \mathrm{~g} /$ liter). Cultures were grown in 250-ml Erlenmeyer flasks containing $50 \mathrm{ml}$ of medium; the flasks were incubated at $28^{\circ} \mathrm{C}$ on rotary shakers $(250 \mathrm{rpm})$. Cells were harvested after 7 days, and growth was measured by determining dry weight. Tests were concluded after one subculture on each nitrogen source.

Cell wall and phospholipid analyses. Cell wall analyses were performed by the method of Becker et al. (3), and whole-cell hydrolysates were analyzed by the methods of Becker et al. (2) and Lechevalier (17). Phospholipid analyses were performed by the methods of Lechevalier et al. (18).

\section{RESULTS}

Morphology. Strain SK\&F-BC2496 ${ }^{\mathrm{T}}$ has the general morphological features that were described by Couch (4) for the genus Streptospor- 


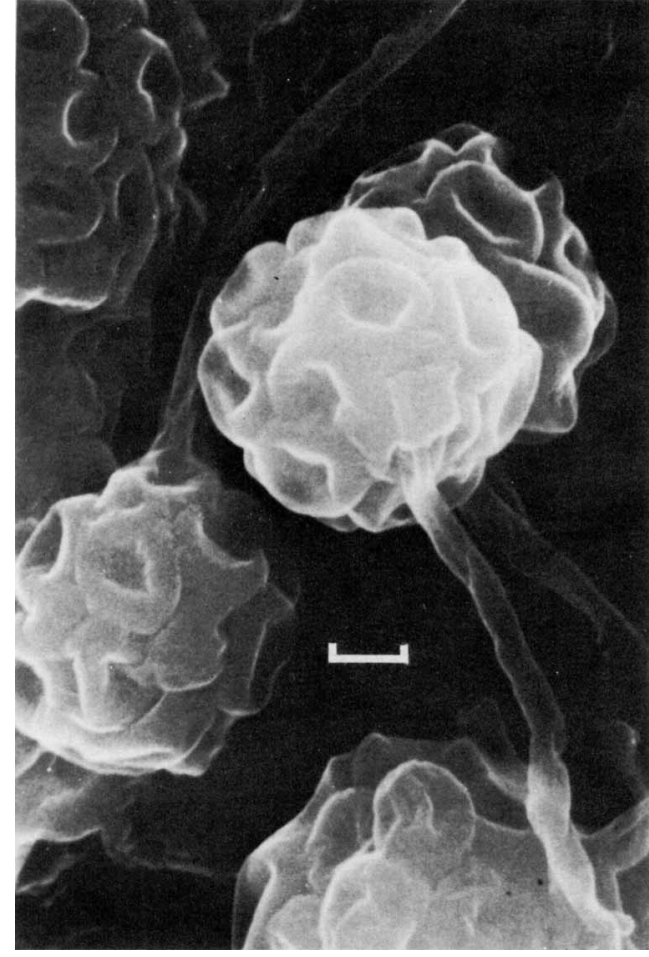

FIG. 1. Scanning electron micrograph of a sporangium from a 14-day-old culture. $\mathrm{Bar}=0.8 \mu \mathrm{m}$.

angium. It is a gram-positive, non-acid-fast organism that forms a substrate mycelium with hyphae about 0.5 to $1.0 \mu \mathrm{m}$ in diameter and an aerial mycelium that bears sporangia. The sporangia are usually 6 to $12 \mu \mathrm{m}$ in diameter and may be formed apically on main threads or on very short to relatively long lateral branches; a few appear to be sessile. The immature sporangiospores are arranged in coils within the sporangia. Mature sporangiospores are spherical to ovoid and nonmotile. The sporangial membranes are unusually fragile and could be demonstrated clearly only by electron microscopy (Fig. 1 and 2). This fragility of the sporangial membranes results in the coalescence of the sporangiospores into large irregular masses as the cultures age (Fig. 3).

Cell chemistry. Purified cell wall preparations of strain SK\&F-BC2496 ${ }^{\mathrm{T}}$ contained mesodiaminopimelic acid, glutamic acid, alanine, glucosamine, and muramic acid; no characteristic sugars were present. Whole-cell hydrolysates contained madurose. Phospholipid preparations contained phosphatidylinositol, phosphatidylethanolamine, phosphatidylmethylethanolamine, cardiolipin, and unknown glucosaminecontaining phospholipids. Therefore, strain SK\&F-BC2496 ${ }^{\mathrm{T}}$ has a type III cell wall (19) with a type B whole-cell sugar pattern (19) and a type
PIV phospholipid composition (18), which are characteristic of the genus Streptosporangium $(18,19)$.

Soluble pigment. Strain SK\&F-BC2496 ${ }^{\mathrm{T}}$ produced a brown soluble pigment on nearly all media. The exact nature of this pigment was not determined. However, based on the chromatographic columns used to isolate the antibiotic and perform the phospholipid analyses, we determined that this pigment is a mixture of a number of colored pigments which, when combined, give the brown color.

Appearance on various media. In this study all cultures were observed for 3 weeks. The colors of the cultures were determined by comparison with chips from either the ISCC-NBS Centroid Color Charts $(15,21)$ or the Munsell Book of Color (20). The characteristics of the culture on the media tested are given below.

Yeast extract-malt extract agar: growth excellent, black; aerial mycelium scant to moderate, white, turning light pink; sporangia abundant; soluble pigment light brown.

Oatmeal agar: growth good, black (ISCC-NBS 267 , black); aerial mycelium moderate, white, turning light pink (ISCC-NBS 8, grayish pink); sporangia abundant; soluble pigment light brown.

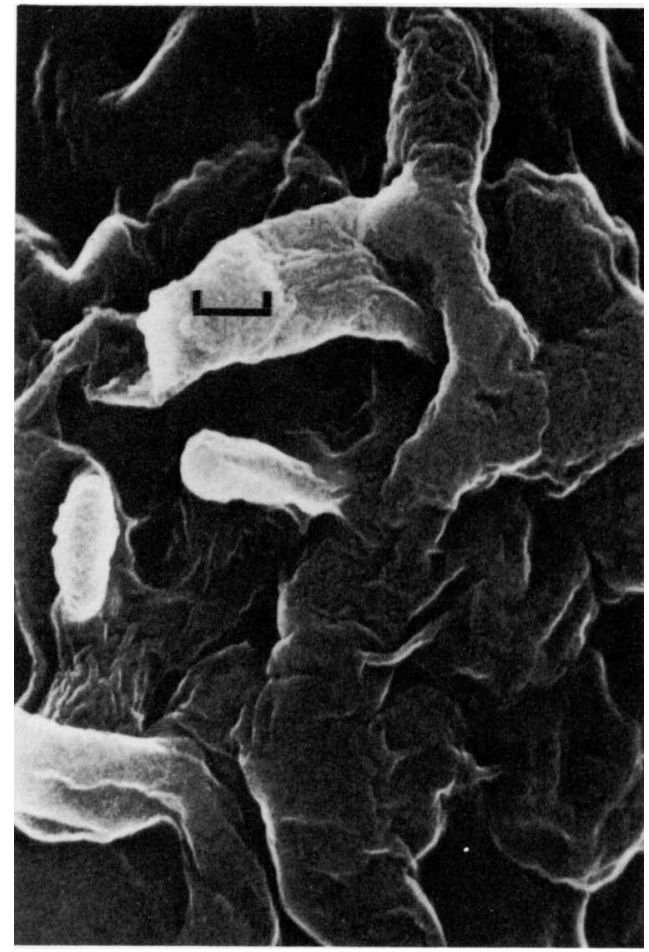

FIG. 2. Scanning electron micrograph of a sporangial membrane from a 14-day-old culture. Bar $=0.4$ $\mu \mathrm{m}$. 


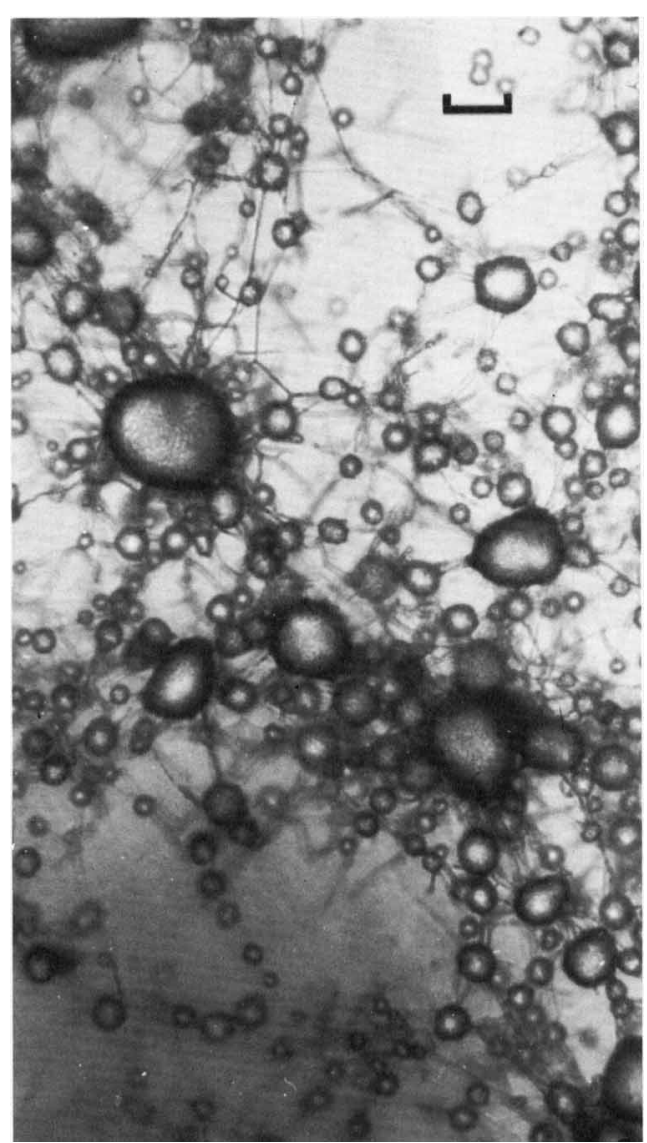

FIG. 3. Micrograph of sporangiospores coalescing into irregular masses. The culture was grown on oatmeal agar and examined by bright-field microscopy. $B a r=20 \mu \mathrm{m}$.

Inorganic salts-starch agar: growth good, brownish black; aerial mycelium moderate, white, turning light pink (Munsell 5R 9/2); sporangia abundant; soluble pigment light brown.

Glycerol-asparagine agar: growth fair, flat, brown; aerial mycelium sparse, white; sporangia none to sparse; soluble pigment light brown.

Potato dextrose agar: growth fair to good, black; aerial mycelium abundant, white, turning pink (Munsell 2.5YR 9/2); sporangia abundant; soluble pigment light brown.

Thin potato-carrot agar: growth fair, flat, black; aerial mycelium sparse, white, turning light pink; sporangia abundant; soluble pigment light brown.

Czapek-sucrose agar: growth poor, flat, brown; aerial mycelium scant, white; no sporangia; soluble pigment light brown.

Bennett agar: growth good, black; no aerial mycelium; soluble pigment brown.

Czapek-peptone agar: growth fair, brown; no aerial mycelium; soluble pigment light brown.

Emerson YpSs agar: growth good, black; aerial mycelium scant, white; no sporangia; soluble pigment brown.

Medium 172: growth excellent, black; aerial mycelium none to sparse, white; sporangia none to moderate; soluble pigment brown.

Tyrosine agar: growth fair, brown; aerial mycelium sparse, white; no sporangia; soluble pigment light brown.

Defined agar: no growth.

Physiological and biochemical characteristics. Strain SK\&F-BC2496 ${ }^{\mathrm{T}}$ did not grow under anaerobic conditions. The temperature range for growth was 15 to $45^{\circ} \mathrm{C}$; no growth occurred at 10 or $50^{\circ} \mathrm{C}$. Hydrogen sulfide was produced. Milk was peptonized. Gelatin was hydrolyzed but not liquefied. Nitrate was reduced to nitrite. Starch, casein, L-tyrosine, and hypoxanthine were hydrolyzed, but urea, adenine, and xanthine were not. Esculin was decomposed, but allantoin and hippurate were not. No growth was produced in lysozyme broth. Catalase was produced. No violet crystals of iodinin were produced in any medium.

Acid was produced from L-arabinose, D-cellobiose, dextrin, dextrose, i-erythritol, D-fructose, D-galactose, glycogen, lactose, maltose, D-mannitol, D-mannose, $\alpha$-methyl-D-glucoside, rhamnose, D-ribose, salicin, starch, trehalose, and Dxylose. No acid was produced from adonitol, dulcitol, inulin, melibiose, raffinose, or $\alpha$-methyl-D-mannoside. Acid production during an initial culture in medium containing glycerol, $\mathrm{i}$ inositol, D-melezitose, D-sorbitol, L-sorbose, or sucrose was variable, but when the organism was subcultured in media containing these carbohydrates the results were consistently negative. Citrate, malate, succinate, lactate, and pyruvate were utilized; utilization of mucate was weakly positive. During an initial culture in media containing acetate and propionate, these organic acids were utilized, but when the organism was subcultured, the results were variable. Benzoate and tartrate were not utilized. During an initial culture in media containing oxalate and formate, utilization was variable; when the organism was subcultured, the results were consistently negative.

Strain SK\&F-BC2496 ${ }^{\mathrm{T}}$ did not require vitamins for growth in the synthetic medium used. Either ammonium sulfate or the combination of ammonium sulfate and $\mathrm{L}$-asparagine was a satisfactory nitrogen source; L-asparagine or sodium nitrate permitted little, if any, growth.

\section{DISCUSSION}

Strain SK\&F-BC2496 ${ }^{\mathrm{T}}$ was compared with all of the Streptosporangium species listed in Bergey's Manual of Determinative Bacteriology (6) 
TABLE 1. Comparison of strain SK\&F-BC2496 ${ }^{\mathrm{T}}$ with Streptosporangium species having pink aerial masses ${ }^{a}$

\begin{tabular}{|c|c|c|c|c|c|c|c|c|}
\hline Organism & $\begin{array}{l}\text { Color of } \\
\text { substrate } \\
\text { mycelium }\end{array}$ & $\begin{array}{l}\text { Color of } \\
\text { soluble } \\
\text { pigment }\end{array}$ & $\begin{array}{l}\text { Shape } \\
\text { of } \\
\text { spores }\end{array}$ & $\begin{array}{l}\text { Growth } \\
\text { at } 42^{\circ} \mathrm{C}\end{array}$ & $\begin{array}{l}\text { Nitrate } \\
\text { reduc- } \\
\text { tion }\end{array}$ & $\begin{array}{l}\text { Starch } \\
\text { hydrol- } \\
\text { ysis }\end{array}$ & $\begin{array}{l}\text { Iodinin } \\
\text { produc- } \\
\text { tion }\end{array}$ & $\begin{array}{l}\text { Refer- } \\
\text { ence }\end{array}$ \\
\hline SK\&F-BC2496 ${ }^{\mathrm{T}}$ & $\begin{array}{c}\text { Dark brown } \\
\text { to black }\end{array}$ & Brown & Oval & + & + & + & - & \\
\hline $\begin{array}{l}\text { Streptosporangium } \\
\text { amethystogenes }\end{array}$ & Yellow-brown & Yellow-brown & Oval & - & + & + & + & 22 \\
\hline $\begin{array}{l}\text { Streptosporangium } \\
\text { longisporum }\end{array}$ & $\begin{array}{l}\text { Red to } \\
\quad \text { brown-red }\end{array}$ & None & Cylindrical & - & \pm & + & - & 24 \\
\hline $\begin{array}{l}\text { Streptosporangium } \\
\text { nondiastaticum }\end{array}$ & Orange & Yellow-brown & Oval & + & + & - & - & 23 \\
\hline $\begin{array}{c}\text { Streptosporangium } \\
\text { pseudovulgare }\end{array}$ & $\begin{array}{l}\text { Orange to } \\
\text { yellow-brown }\end{array}$ & Yellow-brown & Oval & + & + & + & - & 23 \\
\hline $\begin{array}{l}\text { Streptosporangium } \\
\text { roseum }\end{array}$ & $\begin{array}{l}\text { Red-brown to } \\
\text { yellow-brown }\end{array}$ & $\begin{array}{l}\text { Red-brown to } \\
\text { purple-brown }\end{array}$ & Spherical & - & + & + & - & 4 \\
\hline $\begin{array}{l}\text { Streptosporangium } \\
\text { violaceochromo- } \\
\text { genes }\end{array}$ & $\begin{array}{l}\text { Yellow to } \\
\text { orange }\end{array}$ & Violet & Oval & - & + & + & - & 14 \\
\hline $\begin{array}{l}\text { Streptosporangium } \\
\text { vulgare }\end{array}$ & $\begin{array}{l}\text { Yellow to } \\
\text { pale orange }\end{array}$ & $\begin{array}{l}\text { Yellow to } \\
\text { pale orange }\end{array}$ & Oval & - & - & + & - & 22 \\
\hline
\end{tabular}

$a+$, Positive; - , negative; \pm , none or a little.

and on the Approved Lists of Bacterial Names (26); particular emphasis was placed on those Streptosporangium species having pink aerial masses (Table 1). Strain SK\&F-BC2496 ${ }^{\mathrm{T}}$ was easily distinguished from all other species on the basis of its dark brown to black vegetative mycelium. Another distinguishing characteristic was the fragility of its sporangial membranes and the consequent tendency of the sporangiospores to coalesce into large irregular masses. This tendency was observed in only one other species, Streptosporangium violaceochromogenes, which was quite different from strain SK\&FBC2496 ${ }^{\mathrm{T}}$ in other morphological and physiological characteristics (Table 1). Therefore, we regard strain SK\&F-BC2496 ${ }^{\mathrm{T}}$ as a new species for which we propose the name Streptosporangium fragile (fra'gi.le. L. adj. fragile easily broken, fragile, an allusion to the fragility of the sporangial membrane). Strain SK\&F-BC2496, the type strain of $S$. fragile, has been deposited in the American Type Culture Collection, Rockville, Md., as strain ATCC 31519.

\section{ACKNOWLEDGMENTS}

We are deeply indebted to Lee D. Simon for the scanning electron micrographs and to Mary P. Lechevalier for the phospholipid and pure cell wall analyses.

\section{LITERATURE CITED}

1. American Type Culture Collection. 1980. Catalogue of strains I, 14th ed. American Type Culture Collection, Rockville, Md.

2. Becker, B., M. P. Lechevalier, R. E. Gordon, and H. A. Lechevalier. 1964. Rapid differentiation between Nocardia and Streptomyces by paper chromatography of whole-cell hydrolysates. Appl. Microbiol. 12:421-423.

3. Becker, B., M. P. Lechevalier, and H. A. Lechevalier. 1965. Chemical composition of cell-wall preparations from strains of various form-genera of aerobic actinomycetes. Appl. Microbiol. 13:236-243.

4. Couch, J. N. 1955. A new genus and family of the Actinomycetales, with a revision of the genus Actinoplanes. J. Elisha Mitchell Sci. Soc. 71:148-155.

5. Couch, J. N. 1963. Some new genera and species of the Actinoplanaceae. J. Elisha Mitchell Sci. Soc. 79:53-70.

6. Couch, J. N., and C. E. Bland. 1974. Family IV. Actinoplanaceae, p. 706-723. In R. E. Buchanan and N. E. Gibbons (ed.), Bergey's manual of determinative bacteriology, 8th ed. The Williams \& Wilkins Co., Baltimore.

7. Emerson, R., and C. M. Wilson. 1954. Interspecific hybrids and the cytogenetics and cytotaxonomy of Euallomyces. Mycologia 46:393-434.

8. Gordon, R. E. 1966. Some criteria for the recognition of Nocardia madurae (Vincent) Blanchard. J. Gen. Microbiol. 45:355-364.

9. Gordon, R. E. 1967. The taxonomy of soil bacteria, p. 293-321. In T. R. G. Gray and D. Parkinson (ed.), The ecology of soil bacteria. Liverpool University Press, Liverpool.

10. Gordon, R. E., and J. M. Mihm. 1962. Identification of Nocardia caviae (Erikson) nov. comb. Ann. N.Y. Acad. Sci. 98:628-636.

11. Higgins, M. L., M. P. Lechevalier, and H. A. Lechevalier. 1967. Flagellated actinomycetes. J. Bacteriol. 93:14461451.

12. Jensen, H. L. 1930. Actinomycetes in Danish soils. Soil Sci. 30:59-77.

13. Jones, K. L. 1949. Fresh isolates of actinomycetes in which the presence of sporogenous aerial mycelia is a fluctuating characteristic. J. Bacteriol. 57:141-145.

14. Kawamoto, I., S. Takasawa, R. Okachi, M. Kohakura, I. Takahashi, and T. Nara. 1975. A new antibiotic, victomycin (XK 49-1-B-2). I. Taxonomy and production of the producing organism. J. Antibiot. 28:358-365.

15. Kelly, K. L., and D. B. Judd. 1976. Color: universal language and dictionary of names. Special publication 440. National Bureau of Standards, Washington, D.C.

16. Lechevalier, H. A., M. Solotorovsky, and C. I. McDurmont. 1961. A new genus of the Actinomycetales: Micropolyspora gen. nov. J. Gen. Microbiol. 26:11-18.

17. Lechevalier, M. P. 1968. Identification of aerobic actinomycetes of clinical importance. J. Lab. Clin. Med. 71:934-944.

18. Lechevalier, M. P., C. DeBièvre, and H. Lechevalier. 1977. 
Chemotaxonomy of aerobic actinomycetes: phospholipid composition. Biochem. Syst. Ecol. 5:249-260.

19. Lechevalier, M. P., and H. Lechevalier. 1970. Chemical composition as a criterion in the classification of aerobic actinomycetes. Int. J. Syst. Bacteriol. 20:435-443.

20. Munsell Color Co., Inc. 1973. Munsell book of color, neighboring hues edition, matte finish collection. Munsell Color Co., Inc., Baltimore.

21. National Bureau of Standards. 1955. ISCC-NBS centroid color charts. Supplement to NBS circular 553. Standard sample 2106. Office of Standard Reference Materials, National Bureau of Standards, Washington, D.C.

22. Nonomura, H., and Y. Ohara. 1960. Distribution of actinomycetes in soil. $\mathrm{V}$. The isolation and classification of the genus Streptosporangium. J. Ferment. Technol. 38:405409.

23. Nonomura, H., and Y. Ohara. 1969. Distribution of actinomycetes in soil. VI. A culture method effective for both preferential isolation and enumeration of Microbispora and Streptosoporangium strains in soil, part 2. Classification of the isolates. J. Ferment. Technol. 47:701-709.

24. Schäefer, D. 1969. Eine neue Streptosporangium-Art aus türkischer Steppenerde. Arch. Microbiol. 66:365-373.

25. Shirling, E. B., and D. Gottlieb. 1966. Methods for characterization of Streptomyces species. Int. J. Syst. Bacteriol. 16:313-340.

26. Skerman, V. B. D., V. McGowan, and P. H. A. Sneath (ed.). 1980. Approved lists of bacterial names. Int. J. Syst. Bacteriol. 30:225-420. 